\title{
Factors Associated with Antiretroviral Treatments Failure among HIV-Positive Patients in Congo: A Retrospective Cohort Study
}

\author{
Gilbert Ndziessi ${ }^{1 *}$, Axel Julius Aloumba², Darius Eryx Mbou Essie1, Ange Clauvel Niama1, \\ Fresnovie Geladore Mbele', Merlin Diafouka ${ }^{3}$, Ange Antoine Abena ${ }^{4}$ \\ ${ }^{1}$ Department of Public Health, Faculty of Health Sciences, Marien Ngouabi University, Brazzaville, Congo \\ ${ }^{2}$ Infectious Diseases Unit, University Hospital Centre of Brazzaville, Brazzaville, Congo \\ ${ }^{3}$ HIV Outpatient Treatment Centre, Brazzaville, Congo \\ ${ }^{4}$ Laboratory of Biochemistry and Pharmacology, Faculty of Health Sciences, Marien Ngouabi University, Brazzaville, Congo \\ Email: *ndziessi@yahoo.fr
}

How to cite this paper: Ndziessi, G., Aloumba, A.J., Essie, D.E.M., Niama, A.C., Mbele, F.G., Diafouka, M. and Abena, A.A. (2020) Factors Associated with Antiretroviral Treatments Failure among HIV-Positive Patients in Congo: A Retrospective Cohort Study. World Journal of AIDS, 10, 201-214. https://doi.org/10.4236/wja.2020.104018

Received: November 9, 2020

Accepted: December 25, 2020

Published: December 28, 2020

Copyright $\odot 2020$ by author(s) and Scientific Research Publishing Inc. This work is licensed under the Creative Commons Attribution International License (CC BY 4.0).

http://creativecommons.org/licenses/by/4.0/

(c) (i) Open Access

\begin{abstract}
Background: Viral load is the key indicator of the effectiveness of antiretroviral treatment in HIV patients. Study aimed to determine antiretroviral treatments failure rates and associated risk factors among HIV-infected adult patients in Congo. Methods: Data from the Congolese AIDS and Epidemics Control Council were combined to create a historical cohort. Patients were followed up between 2003 to 2017. Mixed logistic regression was used to identify treatment failure associated-factors. Intercooled Stata 10 (StataCorp LP, College Station, Texas, USA) software packages was used for analysis. Results: Over 14 years of follow-up, a total of 25,500 visits for 6391 adult patients were reported. Among them, $88 \%$ i.e. 22,328 visits (for a total of 6127 patients) were visits with treatment failure. In the multivariate analysis, being aged $>26$ years, having primary education level, being student, others nationality, unspecifiedmarital status and being worker in informal sector were found associated with a higher risk of treatment failure. Conversely, being pensioners, receiving second line therapeutic protocols and having good adherence to treatment were found significantly associated with a lower risk of treatment failure. Conclusion: Antiretroviral treatments failure among HIVtreated patients is common in Congo. Developing treatment adherence-centered interventions with focus in patients who have low socio-economic status needed to reduced treatments failure. As treatment failure is not only determined by individual factors, psychosocial supports and availability of antiretroviral drugs needs to be taken into account.
\end{abstract}




\section{Keywords}

Congo, HIV, Antiretroviral Therapy, Treatment Failure, Risk Factors

\section{Introduction}

The human immunodeficiency virus (HIV) epidemic has affected populations around the world. In 2019, 38 million people globally were living with HIV, 1.7 million people became newly infected with HIV and 690,000 died from acquired immunodeficiency syndrome (AIDS)-related illnesses and Africa remains the continent with the highest number of cases, new infections and deaths [1].

Since the introduction of highly active antiretroviral therapy in 1996, there has been a significant reduction in HIV-related mortality rates [2] and effective treatment leads to better clinical and virological outcomes [3]. But, many patients on treatment experienced Virological and immunological failure in developing countries. For example, in Brazil, in a historical cohort study of 76,950 HIV patients aged 34 years on average, $85.2 \%$ achieved viral load suppression after 6 months of treatment [4] while in Uganda this proportion was $11 \%$ in a sample of 100,678 patients [5]. Factors associated with non-suppression of viral load vary from country to country and include co-morbidity, CD4 count, injection drug use, age, late diagnosis, type of treatment, drug pharmacokinetics, resistance to treatment and adherence [6]-[11].

Among people living with HIV, viral load suppression is one of the 10 global indicators for World Health Organization (WHO) guidelines on HIV infection information. This indicator is used to assess the United Nations Programme on HIV/AIDS (UNAIDS) latest "goal 90": to ensure that $90 \%$ of people on antiretroviral treatment have permanently suppressed viral load by 2020 [12]. Viral load suppression is therefore becoming a key indicator in HIV surveillance, not only improving the quality of life of People Living with HIV but is also an effective means of preventing sexual [13].

In Congo, VIH seroprevalence was estimated at 3.2\% in 2009 among people aged 15 and 49 years [14]. Based in this prevalence, in 2020 approximately 128 000 adults are living with HIV/AIDS in Congoand 16\% are receiving antiretroviral treatment. For care, to date, there are 83 care centres. Antiretroviral treatment is offered to all people living with HIV after confirmation of diagnosis and clinical evaluation according national therapeutic guidelines. Antiretrovirals treatment (ART) initiation is offered on the same day to people who are ready to start. The efficacy of ART is defined as the maintenance of a viral load $<50$ copies/ml after 6 months of continuous treatment and failure determined by a viral load $>1000$ copies $/ \mathrm{ml}$ confirmed for at least 6 months after correcting adherence problems in a patient.

However, studies on virological response to ART in Congo are sparse, available studies have found that the proportions of patients with incomplete virologi- 
cal suppression at 6 months and 12 months were 70\% and 89.4\% [15] [16], respectively after initiation of treatment. To our knowledge, no study has been carried out to date on the effectiveness and failure of long-term treatment of antiretroviral treatments used in the care units for HIV-infected patients in the Congo. In this context, this study aimed to determine antiretroviral treatments failure rates and associated risk factors among HIV-infected adult patients in Congo.

\section{Methods}

\subsection{Study Design and Procedures}

Data used in this study are from the survey on the Evaluation of Therapeutic Management of HIV Patients in CongoEVAL-CO. Eval-Co is a historical Cohort study in which 18,000 patients were follow-up in all care centres between 2003 to 2017. Main objective of EVAL-CO was to assess the survival of HIV patients after treatment initiation in Congo. The secondary objectives were: 1) assess retention of patients on antiretroviral therapy, 2) measure the proportions of patients with CD4 cell counts below $<350$ cells $/ \mathrm{mm}^{3}$ among those with initial CD4 cell counts, 3) assess the virological efficacy of treatment regimens, and 4) measure the incidence of tuberculosis and hepatitis B in people living with HIV in Congo. The Eval-Co database were compiled from the fragmented databases of the various health facilities in congo including data in first (Visit 0 ) and follow-up visits. Patient records were eligible if the patient was registered as HIV-infected. The other inclusion criteria were to have started ART between 2003 and 2017, to be at least 18 years old at treatment initiation, to have at least one follow-up visit after treatment initiation. At inclusion, following data were collected: sociodemographic data (Date of birth, sex, nationality, education level, marital status), clinical data (HIV status, weight, height, WHO stage), standard biological data (ASAT, ALAT, blood glucose, amylase, creatinine, blood cholesterol and triglyceride levels), virological data (Plasma viral load, CD4 T cell count). During follow-up, in the first two years, data were collected according to the following schedule: Day 15, Months 1 (M1), M3, M6, M9, M12, M15, M18, M21 and M24; then every 6 months until the 13th year after starting treatment. For these different dates the following data were collected: clinical data (therapeutic protocols, weight, WHO stage and information on therapeutic adherence), comorbidities (tuberculosis, viral hepatitis, malaria at each visit), vital status (death or loss of follow-up), virological data (viral load, CD4 T cell count from the 6th month of treatment then every 6 months until the 14th year). Therapeutic regimens for providing care to HIV patients in the Congo are classified in two periods: Before (Lines published in 2014) and after (Lines published in 2018). Details are in Table 1 .

\subsection{Variables}

Variables retained for the analyses were classified into the following categories: 
Table 1. Overview of therapeutic regimens for providing care to HIV patients, Republic of Congo.

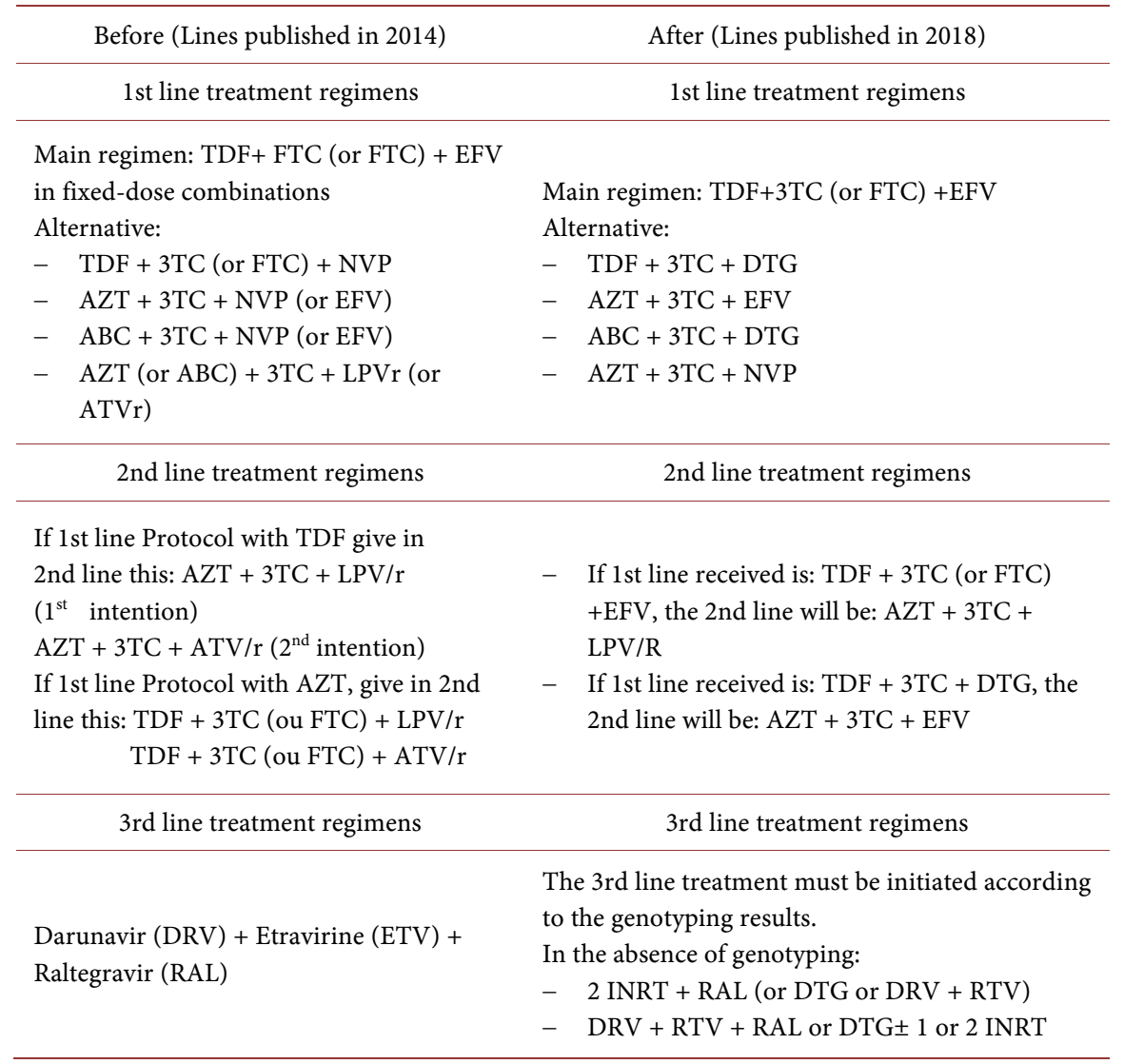

- Socio-demographic characteristics: Gender (Male/Female), age (years), marital status (not in union, in union, divorced/widowed, nospecified), level of education (none, primary; secondary, university; unspecified), nationality (Congolese, other nationalities, unspecified), occupation in six modalities (none, student, formal sector, informal sector, retired, unspecified), care site (Centre for Health Care in Brazzaville, Centre for Health Care in Pointe Noire);

- HIV-related variables: CD4 count at initiation of treatment $\left(<200 \mathrm{cell} / \mathrm{mm}^{3}\right.$; $200-350 \mathrm{cell} / \mathrm{mm}^{3} ;>350=$ cell $\left./ \mathrm{mm}^{3}\right)$, plasma viral load per visit $($ Copies $/ \mathrm{ml})$, therapeutic protocols ( $1^{\text {st }}$ line, $2^{\text {nd }}$ line, $3^{\text {rd }}$ line).

- Psychosocial variable i.e., adherence to therapy.

To assess therapeutic adherence, we used the following procedure:

a) assessment of the treatment period with the following formula:

1) Date of last dispensation - Date of first dispensation

b) Estimate the number of days in which patient has taken his pills, using the following formula:

2) Number pills received for all dispensation/ Expected number of pills per day

c) Measure the proportion of tablets consumed by the patient during the selected period, using the following formula: 
3) Number of days in which patient has taken his pills/Number of consumption days expected $\times 100$

Finally, two modalities of the compliance variable: patients who had a proportion of pills use of $<95 \%$ [17] [18] in the time between the study visits were considered as have "poor adherence". On the other hand, patients with a proportion of drug use of at least $95 \%$ were considered as have "good adherence".

\subsection{Definition of the Treatment Failure}

Virological response to treatment was assessed in patients with viral load (VL) data over the follow-up visit. Patients who had a least one a viral load count $>1000$ copies/ml during the previous 6 months over the first 14 years were considered as patients having treatment failure. On the other hand, Patients who had a least one a viral load count $<1000$ copies/ml during the previous 6 months over the first 14 years were considered as patients with not having treatment failure.

\subsection{Statistical Analysis}

We first described the socio-demographic characteristics of the patients at baseline and estimated the proportion of follow-up visits with unsuppressed viral load. Mixed-effect logistic regression which enable the correlation between repeated measures to be taken into account [34] were used to identify the predictors of treatment failure among HIV patients. Variables with a p-value lower than 0.20 in univariate analyses were considered eligible to enter the initial multivariate model (i.e., age, marital status, level of education, professional sector, follow-up centre, adherence to treatment). The final multivariate model was obtained using a backward stepwise selection procedure based on the log-likelihood ratio test to eliminate non-significant variables $(p>0.05)$ from the initial model. Statistical analyses were performed using Intercooled Stata 10 (StataCorp LP, College Station, Texas, USA) software packages.

\subsection{Ethical Considerations}

The study protocol was approved by institutional ethics committee of the health sciences faculty (Brazzaville, Congo). We used data collected for routine patient care at all health facilities in Congo and submitted to the Conseil National de Lutte contre le Sida et les Epidémies (CLNSE) which is mandated to conduct centralized HIV data in Congo. All data did not carry personal identifiers. The data were not accessible by any other third parties other than the study team. Permission to use the data was sought from the Congo Ministry of Health.

\section{Results}

\subsection{Baseline Characteristics of the Study Population $(n=6924)$}

The main characteristics of the study population are presented in the Table 2. From 2003 to 2019, 19306 patients started ART, of whom 6924 (36\%) had information available and were included in the study. At initiation of antiretroviral 
Table 2. Main characteristics of study population $(\mathrm{N}=6924$ patients $\mathrm{VIH})$.

\begin{tabular}{|c|c|c|}
\hline Variables & Frequency & $\%$ \\
\hline \multicolumn{3}{|l|}{ Gender } \\
\hline Female & 4902 & 71 \\
\hline Male & 2022 & 29 \\
\hline \multicolumn{3}{|l|}{ Age (years) } \\
\hline $18-25$ & 464 & 7 \\
\hline $26-45$ & 5463 & 79 \\
\hline$>45$ & 990 & 14 \\
\hline \multicolumn{3}{|l|}{ Matrimonial status } \\
\hline Not in union & 111 & 2 \\
\hline In union & 132 & 2 \\
\hline Divorced/widowed & 76 & 1 \\
\hline No specified & 6605 & 95 \\
\hline \multicolumn{3}{|l|}{ Education level } \\
\hline None & 104 & 1 \\
\hline Primary & 1260 & 18 \\
\hline Secondary & 5041 & 73 \\
\hline University & 526 & 8 \\
\hline \multicolumn{3}{|l|}{ Nationality } \\
\hline Congolese & 346 & 5 \\
\hline Others & 14 & 0 \\
\hline No specified & 6564 & 95 \\
\hline \multicolumn{3}{|l|}{ Professional activity } \\
\hline Professionally inactive & 1863 & 27 \\
\hline Students & 305 & 4 \\
\hline Formal sector & 755 & 11 \\
\hline Informal sector & 3164 & 46 \\
\hline Pensioners & 90 & 1 \\
\hline No specified & 741 & 11 \\
\hline \multicolumn{3}{|c|}{ Baseline VIH-related characteristics } \\
\hline \multicolumn{3}{|l|}{ With CD4 measures } \\
\hline Yes & 3717 & 54 \\
\hline No & 3207 & 46 \\
\hline With viral load measures & & 0 \\
\hline Yes & 3717 & 54 \\
\hline No & 3207 & 46 \\
\hline
\end{tabular}

therapy, the most represented age group was 26 - 45 years (79\%), 4902 (71\%) were women and the marital status for 6605 (95\%) patients was not indicated. The socioeconomic status of the study population was low with 6931 (92\%) pa- 
tients having level education do not exceed grammar school and 3164 (46\%) were unemployed or worked in the informal sector. In addition, 3717 (54\%) had their CD4 count and viral load measured. Among them, 2114 (57\%) had a CD4 count below 200 cells $/ \mathrm{mm}^{3}$ and 2127 (57\%) had a viral load above 1000 copies $/ \mathrm{ml}$.

\subsection{Treatment Failure among HIV Patients}

Over the whole follow-up, a total of 25,500 visits for 6391 patients was reported. Among them, $88 \%$ i.e., 22,328 visits (for a total of 6127 patients), were visits with treatment failure (i.e., viral load count $>1000$ copies $/ \mathrm{ml}$ ) and for $12 \%$ i.e., 3172 visits (for a total of 364 patients), the viral load was controlled.

\subsection{Factors Associated with Treatment Failure}

As shown in Table 3, variables significantly associated in univariate analysis with a higher risk of treatment failure included the following: being aged $26-35$ years (OR [95\%CI]: 2.207; [1.238 - 3.933], $\mathrm{p}=0.007)$, being aged $36-45$ years (OR [95\%CI]: 2.159 [1.298 - 3.593], $\mathrm{p}=0.003$ ), having unspecified marital status (OR [95\%CI]: 5.109 [3.801 - 6.866], $\mathrm{p}<0.001$ ), having primary education level (OR [95\%CI]: 3.073 [1.812 - 5.213], $\mathrm{p}<0.001)$, having secondary education level (OR [95\%CI]: 1.815 [1.168 -2.820$], \mathrm{p}=0.008)$, having university education level (OR [95\%CI]: 1.665 [1.010 - 2.745], $\mathrm{p}=0.046)$, Being student (OR [95\%CI]: $1.819[1.127-2.936], \mathrm{p}=0.014)$, being worker in the informal sector (OR [95\%CI]: 2.031 [1.596 - 2.585], $\mathrm{p}<0.001)$, living in Pointe Noire (OR [95\%CI]: 3.548 [2.843 - 4.428]) and having initiating treatment from 2014 onwards (OR [95\%CI]: 2.454 [1.832 - 3.288], $\mathrm{p}<0.001)$. Conversely, being widowed/divorced (OR [95\%CI]: 0.752 [0.576 - 0.983], $\mathrm{p}=0.037$ ), being pensioners (OR [95\%CI]: 0.329 [0.228 - 0.475], $\mathrm{p}<0.001)$ and having good adherence to treatment (OR [95\%CI]: $0.006[0.002-0.025], \mathrm{p}<0.001)$ were significantly associated with less risk of treatment failure.

Most of these results were confirmed in multivariate analysis (Table 3). After adjustment, being aged 26 to 35 years (OR [95\%CI]: 2.690 [1.419-5.100], $\mathrm{p}=$ 0.004 ), being aged 26 to 45 years (OR [95\%CI]: 3.665 [2.086 - 6.440], $p<0.001$ ), being aged $>45$ years (OR [95\%CI]: 1.720 [1.001 - 2.954], $\mathrm{p}<0.001)$, having unspecified marital status (OR [95\%CI]: 2.032 [1.108 - 3.727], $\mathrm{p}=0.022$ ), having primary education level(OR [95\%CI]: 2.002 [1.124 - 3.564], $\mathrm{p}=0.018)$, having unspecified nationality (OR [95\%CI]: 2.439[1.288 - 4.620], $\mathrm{p}=0.006$ ), being a student (OR [95\%CI]: 1.820 [1.076 - 3.079], $\mathrm{p}=0.025$ ) and being a worker in the informal sector (OR [95\%CI]: 1.782 [1.386 - 2.291], $\mathrm{p}<0.001$ ) were all associated with a higher risk of having treatment failure. Conversely, being pensioners (OR [95\%CI]: 0.467 [0.316 - 0.690], $\mathrm{p}<0.001$ ), receiving second line therapeutic protocols (OR [95\%CI]: 0.674 [0.505 - 0.899], $\mathrm{p}=0.007$ ) and having good adherence to treatment (OR [95\%CI]: $0.008[0.001-0.032] \mathrm{p}<0.001$,) were significantly associated with a lower risk of treatment failure. 
Table 3. Factors associated with antiretroviral treatments failure among HIV patients in Congo: univariate and multivariate analysis using mixed effects logistic regression (Eval-Co cohort, 25,500 visits for 6391 patients, 14 years of follow-up: 2003-2017).

\begin{tabular}{|c|c|c|c|c|c|c|c|c|}
\hline Variables & $\begin{array}{c}\text { Number } \\
\text { of visits (\%) }\end{array}$ & $\begin{array}{c}\text { Number of } \\
\text { Patients }\end{array}$ & ORbrute & IC $95 \%$ & $\mathrm{P}$ & $\mathrm{OR}_{\text {adusted }}$ & IC à 95\% & $\mathrm{P}$ \\
\hline \multicolumn{9}{|l|}{ Gender } \\
\hline Male (Ref.) & $7967(31.24)$ & 2103 & 1 & & & & & \\
\hline Female & $17,533(68.7)$ & 4861 & 1.029 & {$[0.850-1.247]$} & 0.763 & & & \\
\hline \multicolumn{9}{|l|}{$\begin{array}{l}\text { Age (years) at ART } \\
\text { initiation }\end{array}$} \\
\hline $18-25$ (Ref.) & $1028(4.03)$ & 329 & 1 & & & & & \\
\hline $26-35$ & $3910(15.33)$ & 1141 & 2.207 & {$[1.238$ - 3.933] } & 0.007 & 2.690 & {$[1.419-5.100]$} & 0.004 \\
\hline $36-45$ & $8388(32.89)$ & 2494 & 2.159 & [1.298 - 3.593] & 0.003 & 3.665 & [2.086 - 6.440] & $<0.001$ \\
\hline$>45$ & $12,174(47.74)$ & 3056 & 0.690 & {$[0.432-1.102]$} & 0.121 & 1.720 & {$[1.001-2.954]$} & $<0.001$ \\
\hline \multicolumn{9}{|l|}{ Marital status } \\
\hline Not in union (Ref.) & $3069(1.04)$ & 839 & 1 & & & & & \\
\hline In union & $3784(14.84)$ & 1239 & 0.912 & {$[0.706-1.178]$} & 0.482 & 1.069 & [0.814 - 1.404] & 0.628 \\
\hline Divorced/widowed & $2673(10.8)$ & 819 & 0.752 & {$[0.576-0.983]$} & 0.037 & 0.875 & [0.657 - 1.165] & 0.362 \\
\hline No specified & $15,974(62.64)$ & 3972 & 5.109 & {$[3.801-6.866]$} & $<0.001$ & 2.032 & [1.108 - 3.727] & 0.022 \\
\hline \multicolumn{9}{|l|}{ Education level } \\
\hline None (Ref.) & $569(2.23)$ & 149 & 1 & & & & & \\
\hline Primary & $3750(14.71)$ & 1110 & 3.073 & {$[1.812-5.213]$} & $<0.001$ & 2.002 & {$[1.124-3.564]$} & 0.018 \\
\hline secondary & $18,615(73.00)$ & 5000 & 1.815 & {$[1.168-2.820]$} & 0.008 & 1.020 & {$[0.638-1.644]$} & 0.935 \\
\hline University & $2566(10.06)$ & 797 & 1.665 & {$[1.010-2.745]$} & 0.046 & 1.220 & {$[0.710-2.095]$} & 0.471 \\
\hline \multicolumn{9}{|l|}{ Nationality } \\
\hline Congolese (Ref.) & $9813(38.48)$ & 3049 & 1 & & & & & \\
\hline Others & $384(1.51)$ & 171 & 2.384 & {$[1.118-5.084]$} & 0.024 & 2.068 & {$[0.962-4.442]$} & 0.063 \\
\hline No specified & $15,303(60.01)$ & 3666 & 6.162 & {$[4.776-7.950]$} & $<0.001$ & 2.439 & {$[1.288-4.620]$} & 0.006 \\
\hline \multicolumn{9}{|l|}{ Professional activity } \\
\hline $\begin{array}{l}\text { Professionally } \\
\text { Inactive (Ref.) }\end{array}$ & $7184(28.17)$ & 2007 & 1 & & & & & \\
\hline Students & $1388(5.44)$ & 451 & 1.819 & {$[1.127-2.936]$} & 0.014 & 1.820 & [1.076 - 3.079] & 0.025 \\
\hline Formal sector & $3504(13.74)$ & 1081 & 1.027 & {$[0.787-1.339]$} & 0.842 & 1.215 & [0.914 - 1.615] & 0.179 \\
\hline Informal sector & $10,133(39.74)$ & 3007 & 2.031 & {$[1.596-2.585]$} & $<0.001$ & 1.782 & {$[1.386-2.291]$} & $<0.001$ \\
\hline Pensioners & $497(1.95)$ & 107 & 0.329 & {$[0.228-0.475]$} & $<0.001$ & 0.467 & {$[0.316-0.690]$} & $<0.001$ \\
\hline No specified & $2794(10.96)$ & 1173 & 1.046 & [0.782 - 1.399] & 0.758 & 1.120 & {$[0.824-1.521]$} & 0.467 \\
\hline \multicolumn{9}{|l|}{ Locality } \\
\hline Brazzaville (Ref.) & $8970(40.17)$ & 2573 & 1 & & & & & \\
\hline Pointe Noire & $13,358(59.83)$ & 3606 & 3.548 & {$[2.843-4.428]$} & $<0.001$ & & & \\
\hline \multicolumn{9}{|l|}{$\begin{array}{l}\text { Guideline on ART } \\
\text { eligibility }\end{array}$} \\
\hline Before 2014 (Ref.) & $16,972(76.01)$ & 4584 & 1 & & & & & \\
\hline From 2014 onwards & $5356(23.99)$ & 1595 & 2.454 & {$[1.832-3.288]$} & $<0.001$ & & & \\
\hline
\end{tabular}




\section{Continued}

Therapeutic protocols

$1^{\text {st }}$ line (Ref.)

$2^{\text {nd }}$ line

$3^{\text {rd }}$ line

Adherence

Poor adherence

(Ref.)

Good adherence

$\begin{array}{cc}21,470(89.37) & 555 \\ 2490(10.36) & 54 \\ 64(0.27) & 13\end{array}$

5555

$545 \quad 0.909$

[0.690 - 1.197]

0.498

0.674

[0.505 - 0.899]

0.007

1.520

[0.209- 11.020]

0.678

0.245

[0.0281-2.131]

0.203

14,896 (58.42)

\section{Discussion}

In this study carried out among patients initiating antiretroviral treatments and a follow-up in a long period of 14 years, patients experienced frequently episodes of treatment failure, despite an improvement in access to treatment over the last decade in the Congo, which is consistent with previous studies in AR-treated patients in sub-Saharan African countries [19] [20] [21]. The fact that most of HIV patients treated in Congo having difficulties to achieve undetectable viral load over follow-up can lead to high mortality and limits the effect of treatment as prevention (TasP), thus leading to the persistence of the epidemic. Our results highlight also factors associated with treatment failure. key factors contributing to the high proportion of treatment failure in this study included both individual situations and related to the quality of care provided. Our results also highlight factors associated with treatment failure. The main factors that explain the high proportion of treatment failure in this study are both individual situations and healthcare supply-related. These factors underline difficulties in the management of HIV-infected patients in monitoring units in the Congo. Our study is the first to provide data on long-term treatment failure based on usual treatment regimens in the Congo. This means that our results are of major interest for decision making to improve the quality of care offered to HIV patients within the framework of the national AIDS programme.

Firstly, our study reports that seven out of ten HIV patients are women. The feminisation of the HIV epidemic has already been reported by previous studies in Congo [15] and elsewhere in Africa [5]. In Congo, more HIV patients were recruited in Pointe Noire than compared to Brazzaville $(\mathrm{P}<0.001)$, which consolidates the estimates of the Seroprevalence and AIDS Indicators Survey in Congo (ESISC-I) 2009 survey, which established HIV prevalence at 6.2\% in Pointe Noire and 3.5\% in Brazzaville [14].

Consistent with previous cohort study conducted at University Hospital in Brazzaville [15] or elsewhere in African region [22], low level of education was among most important predictors of treatment failure. It is well reported that low level of education which like poverty is an important systemic determinant of health in low-income countries and calls for major structural changes [23]. 
Results show also that compared to first-line treatment, patients receiving second-line treatment were less likely to have treatment failure viral load, something already shown by previous studies among HIV-patients [24]. In our cohort, only $8 \%$ of patients received second-line protocol drugs. Therefore, there is an urgent need to improve second-line treatment coverage for support the global treatment strategy as a means of prevention [25] [26].

Finally, as reported previously, non-adherence to ART was a major risk factor of treatment failure [5] [6] [7]. To ensure continuous and complete viral suppression, adherence of at least 95\% (i.e. consumed at least 95\% of the prescribed drugs) is required [27] [28] [29] [30]. Or, in this our study, approximately 57\% of patients taking at least $95 \%$ of the tablets. The current result shows that patients with poor adherence is a problem that will in turn affect the UNAIDS global targets of $90 \%$ viral suppression by 2020 [31]. This may indicate the need for more investment and commitment to improving patient adherence in the study area. We reported above that the majority of patients in our study population have economic difficulties. However, adherence to treatment depends on several factors, including the regular acquisition of meals. Indeed, patients who do not have regular meals tend not to take their medication regularly [32] [33]. Thus, strategies to increase adherence to treatment must take into account the fact that it is urgent to provide regular meals to patients who are in financial need. Lack of adherence to treatment is of particular concern here, as poor adherence in HIV patients is associated with higher risk of engaging in unprotected sexual behaviours [34], and thus increasing the spread of HIV.

Despite these interesting results, some study limitations need to be recognized. Firstly, social behavioural factors such as stigmatization and discrimination are major factors associated with viral load as previously reported by several studies [35]-[40]. The major limitation of this study is that these socio-behavioural variables were did not assess because the design of study (i.e., a historical study), so researchers did not have any contact with patients. In addition, using a tablet count for assessing adherence may under or overestimate the proportion of patients with adherence to AR treatment [41]. Even so, we were able to adjust adherence according to VL and were able to show that the higher the VL the lower the adherence.

\section{Conclusion}

Antiretroviral treatments failure among HIV-treated patients is common in Congo. Developing treatment adherence-centred interventions with focus in patients who have low socio-economic status needed to reduced treatments failure. As treatment failure is not only determined by individual factors, psychosocial supports and availability of antiretroviral drugs needs to be taken into account. The high rate of treatment failure indicates the low quality of care. The development of a vast psychological support programme including advice on adherence to treatment, new technologies such as SMS reminders by phone to take the 
prescribed doses and the provision of meals to destitute patients is becoming an essential part of the national AIDS programme.

\section{Author Contributions}

NG had the idea for and designed the study and had full access to all data in the study and take responsibility for the integrity of the data and the accuracy of the data analysis. AN, MFG, MNBU, AA DM and MED contributed to writing of the report. AA contributed to critical revision of the report. GN, MFG and MNBU contributed to the statistical analysis. All authors contributed to data acquisition, data interpretation, reviewed and approved the final version.

\section{Declaration of Interests}

All authors declare no competing interests.

\section{References}

[1] UNAIDS-AIDS Data 2019.

https://www.unaids.org/sites/default/files/media asset/2019-UNAIDS-data en.pdf

[2] Granich, R., et al. (2015) Trends in AIDS Deaths, New Infections and ART Coverage in the Top 30 Countries with the Highest AIDS Mortality Burden; 1990-2013. PLoS ONE, 10, e0131353. https://doi.org/10.1371/journal.pone.0131353

[3] Mocroft, A., et al. (2003) Decline in the AIDS and Death Rates in the EuroSIDA Study: An Observational Study. The Lancet (London, England), 362, 22-29. https://doi.org/10.1016/S0140-6736(03)13802-0

[4] Meireles, M.V., Pascom, A.R.P. and Duarte, E.C. (2018) Factors Associated with Early Virological Response in HIV-Infected Individuals Starting Antiretroviral Therapy in Brazil (2014-2015): Results From a Large HIV Surveillance Cohort. Journal of Acquired Immune Deficiency Syndromes, 78, e19-e27. https://doi.org/10.1097/QAI.0000000000001684

[5] Bulage, L., et al. (2017) Factors Associated with Virological Non-Suppression among HIV-Positive Patients on Antiretroviral Therapy in Uganda, August 2014-July 2015. BMC Infectious Diseases, 17, Article No. 326. https://doi.org/10.1186/s12879-017-2428-3

[6] Ahoua, L., et al. (2009) Risk Factors for Virological Failure and Subtherapeutic Antiretroviral Drug Concentrations in HIV-Positive Adults Treated in Rural Northwestern Uganda. BMC Infectious Diseases, 9, Article No. 81. https://doi.org/10.1186/1471-2334-9-81

[7] Hailu, G.G., Hagos, D.G., Hagos, A.K., Wasihun, A.G. and Dejene, T.A. (2018) Virological and Immunological Failure of HAART and Associated Risk Factors among Adults and Adolescents in the Tigray Region of Northern Ethiopia. PLoS ONE, 13, e0196259. https://doi.org/10.1371/journal.pone.0196259

[8] Biset Ayalew, M., et al. (2016) First-Line Antiretroviral Treatment Failure and Associated Factors in HIV Patients at University of Gondar Teaching Hospital, Gondar, Northwest Ethiopia. HIVIAIDS-Research and Palliative Care, 8, 141-146. https://doi.org/10.2147/HIV.S112048

[9] Wang, J., et al. (2014) Virological Outcomes and Drug Resistance in Chinese Patients after 12 Months of 3TC-Based First-Line Antiretroviral Treatment, 2011-2012. PLoS ONE, 9, e88305. https://doi.org/10.1371/journal.pone.0088305 
[10] Tuboi, S.H., Harrison, L.H., Sprinz, E., Albernaz, R.K.M. and Schechter, M. (2005) Predictors of Virologic Failure in HIV-1-Infected Patients Starting Highly Active Antiretroviral Therapy in Porto Alegre, Brazil. JAIDS Journal of Acquired Immune Deficiency Syndromes, 40, 324-328. https://doi.org/10.1097/01.qai.0000182627.28595.01

[11] Le Moing, V., et al. (2001) Clinical, Biologic, and Behavioral Predictors of Early Immunologic and Virologic Response in HIV-Infected Patients Initiating Protease Inhibitors. JAIDS Journal of Acquired Immune Deficiency Syndromes, 27, 372-376. https://doi.org/10.1097/00126334-200108010-00007

[12] En finir avec le sida-Progresser vers les cibles 90-90-90-Synthèse-Recherche Google.

https://www.google.com/search?client=firefox-b-d\&q=En+finir+avec+le+sida+-+Pr ogresser+vers+les+cibles+90-90-90+-+Synth\%C3\%A8se

[13] Ndziessi, G., et al. (2013) Susceptibility to Transmitting HIV in Patients Initiating Antiretroviral Therapy in Rural District Hospitals in Cameroon (Stratall ANRS 12110/ESTHER Trial). PLoS ONE, 8, e62611. https://doi.org/10.1371/journal.pone.0062611

[14] CNSEE, CNLS, ICF MACRO (2009) Congo, Rep. Enquête de Séroprévalence et sur les Indicateurs du Sida du Congo.

https://microdata.worldbank.org/index.php/catalog/2848

[15] Dokekias, A.E., et al. (2008) Evaluation du traitement antirétroviral chez les adultes infectés par le VIH, suivis dans le service d'hématologie du CHU de Brazzaville, Congo. Bulletin de la Société de Pathologie Exotique, 101, 109-112.

[16] Faure, N., Diafouka, M., Nzounza, P., Ekat, M., Mahambou Nsonde, D., Levaseur, G., et al. (2011) Observance thérapeutique des personnes vivant avec le VIH en 2009 au centre de traitement ambulatoire de Brazzaville, Congo. Médecine Tropicale, 71, 487-491.

[17] Moosa, A., Gengiah, T.N., Lewis, L. and Naidoo, K. (2019) Long-Term Adherence to Antiretroviral Therapy in a South African Adult Patient Cohort: A Retrospective Study. BMC Infectious Diseases, 19, Article No. 775.

https://doi.org/10.1186/s12879-019-4410-8

[18] Paterson, D.L., et al. (2000) Adherence to Protease Inhibitor Therapy and Outcomes in Patients with HIV Infection. Annals of Internal Medicine, 133, 21-30.

[19] Bvochora, T., et al. (2019) Enhanced Adherence Counselling and Viral Load Suppression in HIV Seropositive Patients with an Initial High Viral Load in Harare, Zimbabwe: Operational Issues. PLoS ONE, 14, e0211326. https://doi.org/10.1371/journal.pone.0211326

[20] Glass, T.R., et al. (2019) The Viral Load Monitoring Cascade in a Resource-Limited Setting: A Prospective Multicentre Cohort Study after Introduction of Routine Viral Load Monitoring in Rural Lesotho. PLoS ONE, 14, e0220337.

https://doi.org/10.1371/journal.pone.0220337

[21] Nicholas, S., et al. (2019) Point-of-Care Viral Load Monitoring: Outcomes from a Decentralized HIV Programme in Malawi. Journal of the International AIDS Society, 22, e25387. https://doi.org/10.1002/jia2.25387

[22] Mbengue, M.A.S., Sarr, S.O., Diop, A., Ndour, C.T., Ndiaye, B. and Mboup, S. (2019) Prevalence and Determinants of Adherence to Antiretroviral Treatment among HIV Patients on First-Line Regimen: A Cross-Sectional Study in Dakar, Senegal. The Pan African Medical Journal, 33, 95. https://doi.org/10.11604/pamj.2019.33.95.17248 
[23] Ordóñez, C.E. and Marconi, V.C. (2012) Understanding HIV Risk Behavior from a Sociocultural Perspective. Journal of AIDS \& Clinical Research, 3, e108. https://doi.org/10.4172/2155-6113.1000e108

[24] Cao, P., et al. (2018) Treatment Outcomes and HIV Drug Resistance of Patients Switching to Second-Line Regimens after Long-Term First-Line Antiretroviral Therapy: An Observational Cohort Study. Medicine (Baltimore), 97, e11463. https://doi.org/10.1097/MD.0000000000011463

[25] Cohen, M.S., et al. (2011) Prevention of HIV-1 Infection with Early Antiretroviral Therapy. The New England Journal of Medicine, 365, 493-505. https://doi.org/10.1056/NEJMc1110588

[26] Cohen, M.S., et al. (2016) Antiretroviral Therapy for the Prevention of HIV-1 Transmission. The New England Journal of Medicine, 375, 830-839.

[27] Beltrán, M.A., Gil, R.A. and Nasiff, V. (2018) Non-Compliance with Antiretroviral Treatment and Undetectable HIV Viral Load. Medicina (Mex.), 78, 378-379.

[28] Silveira, M.P.T., Maurer, P., Guttier, M.C. and Moreira, L.B. (2015) Factors Associated with Therapeutic Success in HIV-Positive Individuals in Southern Brazil. Journal of Clinical Pharmacy and Therapeutics, 40, 192-195. https://doi.org/10.1111/jcpt.12233

[29] Cambiano, V., et al. (2010) Use of a Prescription-Based Measure of Antiretroviral Therapy Adherence to Predict Viral Rebound in HIV-Infected Individuals with Viral Suppression. HIV Medicine, 11, 216-224.

https://doi.org/10.1111/j.1468-1293.2009.00771.x

[30] Ingle, S., et al. (2018) Identifying Risk of Viral Failure in Treated HIV-Infected Patients Using Different Measures of Adherence: The Antiretroviral Therapy Cohort Collaboration. Journal of Clinical Medicine, 7, 328. https://doi.org/10.3390/jcm7100328

[31] ONUSIDA. En finir avec le sida-Progresser vers les cibles 90-90-90-Synthèse. https://www.unaids.org/fr/resources/documents/2017/20170720 Global AIDS upd ate 2017

[32] Kaishusha Mupendwa, B.-P. and Kadima Ntokamunda, J.-L. (2009) Treatment Adhesion and Factors Affecting It at the Kadutu Clinic (Democratic Republic of the Congo). Sante (Montrouge, France), 19, 205-215. https://doi.org/10.1684/san.2009.0178

[33] Chop, E., et al. (2017) Food Insecurity, Sexual Risk Behavior, and Adherence to Antiretroviral Therapy among Women Living with HIV: A Systematic Review. Health Care for Women International, 38, 927-944. https://doi.org/10.1080/07399332.2017.1337774

[34] Ndziessi, G., et al. (2012) Adherence as a Predictor of Sexual Behaviors in People Living with HIV/AIDS during the First Year of Antiretroviral Therapy in Rural Cameroon: Data from Stratall ANRS 12110/ESTHER Trial. PLOS ONE, 7, e36118. https://doi.org/10.1371/journal.pone.0036118

[35] Baltazary, G., Akarro, R.R.J. and Mussa, A.S. (2011) Some Factors Associated with Non-Adherence to Antiretroviral Therapy (ART) in People Living with HIV/AIDS (PLHA) in Tanzania: A Case Study of Dar es Salaam Region. East African Journal of Public Health, 8, 237-246.

[36] Filimão, D.B.C., Moon, T.D., Senise, J.F., Diaz, R.S., Sidat, M. and Castelo, A. (2019) Individual Factors Associated with Time to Non-Adherence to ART Pick-Up within HIV Care and Treatment Services in Three Health Facilities of Zambézia Province, Mozambique. PLoS ONE, 14, e0213804. 
https://doi.org/10.1371/journal.pone.0213804

[37] Letta, S., Demissie, A., Oljira, L. and Dessie, Y. (2015) Factors Associated with Adherence to Antiretroviral Therapy (ART) among Adult People Living with HIV and Attending Their Clinical Care, Eastern Ethiopia. BMC International Health and Human Rights, 15, 33. https://doi.org/10.1186/s12914-015-0071-x

[38] Tarekegn, M., Baru, A. and Seme, A. (2019) Levels of Option B+ ART Drugs Adherence and Associated Factors among Pregnant Women Following ART Services at Public Health Facilities of East Shawa Zone, Oromia, Ethiopia. Sexual \& Reproductive Healthcare, 22, Article ID: 100459.

https://doi.org/10.1016/j.srhc.2019.100459

[39] Ntela, S.-D.M., et al. (2018) Observance to Antiretroviral Treatment in the Rural Region of the Democratic Republic of Congo: A Cognitive Dissonance. The Pan African Medical Journal, 31, 159. https://doi.org/10.11604/pamj.2018.31.159.15132

[40] Mbuagbaw, L., et al. (2012) Trends and Determining Factors Associated with Adherence to Antiretroviral Therapy (ART) in Cameroon: A Systematic Review and Analysis of the CAMPS Trial. AIDS Research and Therapy, 9, 37.

https://doi.org/10.1186/1742-6405-9-37

[41] Bastard, M., Fall, M.B.K. and Groupe d'étude de la Cohorte ANRS 1215 (2014) Observance à long terme au traitement antirétroviral au Sénégal. Bulletin de la Société de Pathologie Exotique, 107, 241-243. https://doi.org/10.1007/s13149-014-0346-9 